Egypt. Acad. J. biolog. Sci., 2(2): 21 - 25(2010)

Email: egyptianacademic@yahoo.com

Received: $15 / 6 / 2010$
C. Physiology \& Molecular Biology

ISSN: 2090-0767

www.eajbs.eg.net

\title{
Metabolic Constituents of Urinary Stone Composition in Sudanese Children
}

\author{
Ghada A. Elfadil *, Muntasir E. Ibrahim **, Salah AM. Ahmed ${ }^{* * *}$. \\ Department of Clinical Chemistry, College of Medical Laboratory Science, Sudan \\ University of Science \& Technology, Khartoum, Sudan. \\ ${ }^{* *}$ Faculty of Medicine, University of Khartoum, Sudan. \\ *** Institute of Endemic Disease, University of Khartoum, Sudan.
}

\section{ABSTRACT}

Objectives: The aim of this study was to show the biological characteristics of pediatric urolithiasis in Sudanese patient's population and evaluation of some metabolic risk factors.

Materials and Methods: We analyzed prospectively urinary stones from 175 consecutive children (129 males, 46 females), aged 3 months to 16 years. Patients were reviewed in Soba Teaching Hospital, Khartoum state Sudan, during the period October 2005-May 2009. The chemical analysis of stones was carried out by Urinary Calculi Analysis Kit, manufacturer DiaSys Diagnostic system GmbH.

One hundred and thirty blood samples ( 80 patients, 50 controls) were collected from patients with renal stone to screen some metabolic risk factors, serum calcium, serum phosphate, serum uric acid, and serum creatinine. Fifty samples, of 24 hours urine collection ( 30 patients, 20 controls) were collected to determine the excretion of urine calcium, phosphate and uric acid. It was analyzed by auto analyzer Cobas Integra 400 Plus.

Statistical Analysis: Statistical analysis of data was carried out using software SPSS 11.0 for Windows. Statistical significance was determined using chi-square test $\&$ Fisher exact test.

Results: The sex ratio was 2.8:1 boys to girls Clinical presentation of this pathology was dominated by flank pain $(67 \%)$, urinary tract infection $(49 \%)$ hematuria $(27 \%)$, and acute renal failure $(6.2 \%)$. Stones were located in the upper urinary tract in $74.9 \%$ of cases. Calcium Oxalate was found more frequently in children stones than infants $(\mathrm{P}<0.0001)$ and was the main component in $55.4 \%$ of stones constituents. Cystine stone was more frequent in infant than children $(\mathrm{P}<$ $0.011)$. Uric acid stones were more frequent among boy's stones than girls' ( $8 \% \mathrm{vs}$ $0.6 \%)(\mathrm{P}<0.05)$.

Metabolic urolithiasis cases accounted for $6.3 \%$ of our patients, and earlier onset of symptoms, were more common in patients with positive family history of urolithiasis, increased frequency multiple and bilateral stones were observed in this group compared with the other etiologic groups. There was increase urinary calcium, uric acid excretion in patients with renal stones ( $p>0.009, \mathrm{p}>0.013$ respectively).

Conclusions: urolithiasis is a serious problem among Sudanese children with early onset of presentation. Proper management of UTI with a careful metabolic assessment of young stone formers is valuable in combating urolithiasis.

\section{INTRODUCTION}

The composition and clinical characteristics of urinary calculi in children vary greatly from one part of the world to another and from one historic period to the next(Oner et al. 1997). This variation is related to climate, dietary, genetic, and socioeconomic factors (Kamoun et al. 1999). Urolithiasis (UL) can develop in pediatric patients as a result 
of metabolic disorders, anatomical malformations of the urinary tract, infection, and environmental and nutritional factors (Gearhart et al. 1991).

Urolithiasis in children is a frequent disease characterized by its varied patho physiological background (Angwafo, III et al. 2000) Clinical investigations of a patient with urolithiasis include a careful history, radiological and biochemical evaluation. It is always important to define the cause of urinary calculi disease among children to prevent recurrence and possible impairing of renal function. (Kamoun et al. 1997).A numbers of publications have previously reported the high prevalence and particular patterns of stone disease among children in developing countries (Elder JS 2004). We lack data about Urolithiasis in Sudanese children.

\section{MATERIALS AND METHODS}

Between October 2005 to May 2009, 175 pediatric patients with Urolithiasis, their age between 3 months16 years, in the pediatric Surgery Clinic, Soba Teaching Hospital in Khartoum state. Patients were referred from different regions of Sudan State. Full documentation included recording of age, sex, residency, age of onset of symptoms, age of diagnosis of stone disease, clinical presentation, past medical and surgical history, family history of stone disease, and recurrence (which was considered if the patient had previous surgery or spontaneous passage of stone before presentation).

All stones were documented radiologically by renal ultrasonography (US), conventional X-ray of the abdomen (KUB), and intravenous pyelography (IVP). Stones were analysis by chemical analysis (DiaSys Diagnostic System $\mathrm{GmbH}$, Germeny) and character of the stone (unilateral or bilateral, single or multiple). Metabolic work up was done for patients suffering from multiple or bilateral renal stones. Metabolic work up included assessment of serum levels of calcium, phosphate, uric acid, and creatinine, Urinary 24-hrs collections were done for volume, calcium, phosphate, and uric acid, all the parameter were measured by automated analyzer Cobas Integra 400 Plus.

\section{RESULTS}

Children under study were aged between three months to 16 years (mean age $4.96 \pm 4$ years). $30.1 \%$ of the cases were infants aged less than two years, $44 \%$ aged from 2 to 6 years, and $25 \%$ more than 6 years. Clinical presentation of this pathology was dominated by flank pain $(67 \%)$, urinary tract infection (49\%) hematuria $(27 \%)$, and acute renal failure $(6.2 \%)$. A positive family history of urolithiasis was recorded for 34 patients $(20 \%)$.

Urolithiasis was more frequent among boys. The sex ratio was 2.8:1 (129 boys and 46 girls); ratio was 3.2:1 among infant patients, and 2.7:1 among children. Seventy five percent of the calculi were located in the upper urinary tract system and $25 \%$ in the lower one as in Fig. 1.

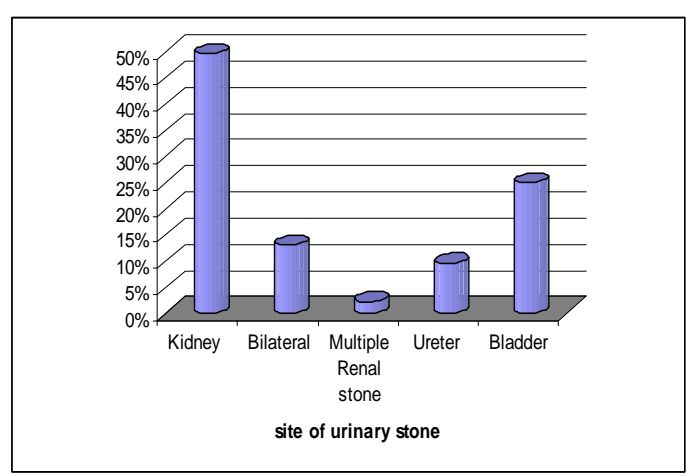

Fig. 1: distributions of urinary calculi according to stone site.

Calcium oxalate stone were the commonest constituents (55.4\%), followed by ammonium urate $(48.6 \%)$, Struvite $(15.9 \%)$, calcium phosphate $(11.4 \%)$, uric acid stones (8\%), and cystine stones $(5.7 \%)$. The components of the upper urinary tract calculi were calcium oxalate $(40 \%)$, ammonium urate $(35.4 \%)$ and calcium phosphate $(21 \%)$, whereas the main components of the lower urinary tract calculi were ammonium acid urate $(23 \%)$, struvite $(9.1 \%)$, and calcium oxalate $(10.4 \%)$.

There was significant association between upper urinary tract and calcium phosphate stones, and cystine stones $\mathrm{P}<$ 
$0.028, \quad 0.045$ respectively, and lower urinary tract with Struvite stones $\mathrm{P}<0.0001$. Cystine stones were more common in patients with positive family history $\mathrm{P}<0.001$.

There was no difference between the mean of total serum calcium, phosphate, serum uric acid, and serum creatinine in patients with renal stone compared to control group as in tables 1 and 2.

Table 1: Metabolic blood screen in patients with renal stone:

\begin{tabular}{|l|l|l|l|}
\hline & $\begin{array}{c}\text { Study group } \\
(\text { Mean } \pm \mathrm{SD})\end{array}$ & $\begin{array}{c}\text { Control group } \\
(\text { Mean } \pm \mathrm{SD})\end{array}$ & $\begin{array}{c}\text { Sig. } \\
(2 \text {-tailed })\end{array}$ \\
\hline S. Calcium & $9.6 \pm 0.85 \mathrm{~g} / \mathrm{dL}$ & $9.5 \pm 0.7 \mathrm{mg} / \mathrm{dL}$ & $<0.56^{*}$ \\
\hline S. Phosphate & $4.3 \pm 0.4 \mathrm{~g} / \mathrm{dL}$ & $4.2 \pm 0.3 \mathrm{mg} / \mathrm{dL}$ & $<0.345^{*}$ \\
\hline S. uric acid & $3.5 \pm 1.1 \mathrm{mg} / \mathrm{dL}$ & $3.5 \pm 1.0 \mathrm{mg} / \mathrm{dL}$ & $<0.979^{*}$ \\
\hline S. creatinine & $0.46 \pm .24 \mathrm{mg} / \mathrm{dL}$ & $0.4 \pm 0.1 \mathrm{mg} / \mathrm{dL}$ & $<0.089^{*}$ \\
\hline
\end{tabular}
* P value $>0.5$ no significant association

Table 2: Metabolic $24 \mathrm{hrs}$ urine excretion screen in patients with renal stone:

\begin{tabular}{|c|c|c|c|}
\hline & $\begin{array}{l}\text { Study group } \\
(\text { Mean } \pm \mathrm{SD})\end{array}$ & $\begin{array}{l}\text { Control group } \\
(\text { Mean } \pm \text { SD) }\end{array}$ & $\begin{array}{l}\text { Sig. (2- } \\
\text { tailed) }\end{array}$ \\
\hline $\begin{array}{l}\text { Calcium } \\
\text { excretion }\end{array}$ & $\begin{array}{ll}1.98 \pm & 0.8 \\
\mathrm{mg} / \mathrm{kg} / \text { day } & \end{array}$ & $\begin{array}{l}1.4 \pm \quad 0.5 \\
\mathrm{mg} / \mathrm{kg} / \text { day }\end{array}$ & $<0.008^{*}$ \\
\hline $\begin{array}{l}\text { Phosphate } \\
\text { excretion }\end{array}$ & $\begin{array}{lll}5.0 \quad \pm & 1.9 \\
\mathrm{mg} / \mathrm{kg} / \mathrm{day} & \end{array}$ & $\begin{array}{l}5.2 \pm 1.2 \\
\mathrm{mg} / \mathrm{kg} / \text { day }\end{array}$ & $<0.626$ \\
\hline $\begin{array}{l}\text { Uric acid } \\
\text { excretion }\end{array}$ & $\begin{array}{ll}1.0 \pm & 0.5 \\
\mathrm{mg} / \mathrm{kg} / \text { day } & \end{array}$ & $\begin{array}{l}0.6 \pm \\
\mathrm{mg} / \mathrm{kg} / \text { day }\end{array}$ & $<0.012 *$ \\
\hline
\end{tabular}

* $\mathrm{P}$ value $>0.5$ no significant association

Evaluation of metabolic risk factors in 24-hour urine samples revealed 45 children $(25.7 \%)$ with a single risk factor. Among these, hypercalciuria (1 case), cystinuria (ten cases). The stone composition, Calcium oxalate stone represent its principal component (55.4\%), which was more frequent in children $(64.4 \%)$ than infants $(35.2 \%)(\mathrm{P}<0.0001)$. Ammonium urate represent $48.6 \%$ of stone constituents. Struvite stone frequency $15.4 \%$ of stones constituents, it was more frequent in lower urinary tract than upper one $(\mathrm{P}<0.0001)$. Calcium phosphate stones were found in $(11.4 \%)$ of stone constituents, it was more frequent in upper urinary tract than lower one $(\mathrm{P}<0.028)$. Purine stones were $(8.6 \%)$ of cases mostly observed in boys ( 8 vs. $0.6 \% \%$ in girls) $(\mathrm{P}<0.043)$.

\section{DISCUSSION}

Our study showed a male predominance with urinary calculi, a boys: girls ratio of
2.8:1; the ratio was 6.3 among patients with lower urinary tract stones and 2.3 among patients with upper urinary tract stones, similar result was found in Egyptian children, male more common than female ratio 2.7; the ratio was 5.3 among patients with lower urinary tract stones and 2.4 among patients with upper urinary tract stones (Aggour et al. 2009), also in Saudi Arabia the ratio was $2.5: 1$ boys to girls (AlRasheed et al. 1995), and different ratio reported by Alaya et al in Tunisia children found that the ratio1.47:1 male: female (Alaya et al. 2009b). Patients were classified according to onset of stones into three age groups. Group I (aged $<2$ years) contained $33.1 \%$ of the patients; $77.8 \%$ were boys and $70 \%$ had stones in the upper urinary tract. Group II (2-6 years) contained $41.7 \%$ of the patients; $73 \%$ were boys and $71 \%$ had stones in the upper urinary tract. Group III ( $>6$ years) contained $25.1 \%$ of the patients; $68 \%$ were boys and $86 \%$ had stones in the upper urinary tract. We hypothesize that the fact that the proportion of patients having upper urinary tract stones increases with age is most probably due to improvement of dietary habits and nutritional status of children.

Children often present with non specific symptoms, especially the younger ones, and less commonly with flank pain or hematuria. However, in this study, the main presenting symptoms were flank pain $(67 \%)$, hematuria (27\%) and dysuria (23\%).In Tunisia children the clinical presentation of urinary calculi pathology was abdominal pain in $28 \%$, hematuria $25.6 \% \%$, and urinary tract infection $14.3 \%$ (Alaya et al. 2009a) .There is a variation in presenting symptoms, especially flank pain, among different countries, which may be related to the degree of awareness in the population and the onset of seeking medical advice.

In Europe, urinary stones are mainly located in the upper urinary tract and the proportion of bladder calculi does not exceed 14\% (Daudon 2000), in Egypt 19\% (Aggour et al., 2008), and Tunisia children 20.2\% (Alaya et al. 2009). It is absent even in other industrialized countries such as the United States of America (Stapleton 2002). Bladder stones were observed only in rural areas of 
developing countries, $51.1 \%$ in Morocco (Oussama et al. 2000), and $71 \%$ in Cameroon (Angwafo, III et al. 2000a). However, in this study bladder stone frequency was $24.6 \%$ of all urinary calculi in study group, and it is more frequent in boys than girls $(29.5 \%$ VS $13 \%) \mathrm{P}<0.029$.

Several studies noted a strong association between urolithiasis and urinary tract infections (Kamoun et al. 1995). It is not always easy to determine if the infection is the cause or the consequence of lithiasis. The frequency of urinary tract infections was about 15 to $57 \%$ of lithiasic patients in the years $1970-$ 1980, and does not exceed 2\% in Europe at present (Jungers et al. 2001). In this study, infection reached $49.1 \%$ of cases comparable with that found in North America 8\% (Sternberg et al. 2005), in England (30\%), (Coward et al. 2003) Kuwait (29\%) (Al-Eisa et al. 2002) and the Egypt 66\% (Aggour et al. 2008).

The chemical analysis of the 175 stones in our study revealed that calcium oxalate is the main component, found in $55.4 \%$ of the patients' stones, followed by ammonium acid urate in $48.6 \%$. The difference in the proportion of ammonium acid urate stones in comparison to studies from other countries and communities, including Tunisia (3\%) and Armenia (5.1\%), may be explained by the hotter climate and poorer dietary habits with subsequent dehydration and uric acid supersaturation.

The components of the upper urinary tract calculi were calcium oxalate $(40 \%)$, ammonium urate $(35.4 \%)$ and calcium phosphate $(21 \%)$, whereas the main components of the lower urinary tract calculi were ammonium acid urate $(23 \%)$, struvite $(9.1 \%)$, and calcium oxalate $(10.4 \%)$. The main components of childhood stones in Europe, in decreasing order, are struvite, calcium phosphate and calcium oxalate (Androulakakis et al. 1991).

The etiology and history of stone formation varies in different populations and it is represented by anatomical abnormalities, metabolic studies, dietary habits and stone composition. This study identified etiological causes in $21.7 \%$ of the175 cases in which records were available, including $5.7 \%(10 / 175)$ that were classified as cystinuria, $15.4 \%$ as infection stone, $0.5 \%$ as anatomic abnormalities and $0.5 \%$ hypercalcuria. Overall predisposing factors can be identified in $30 \%$ to $80 \%$ of the patients depending where the studies were done (Milliner and Murphy 1993; Fraser et al. 1999a; Pietrow et al. 2002a) In developing countries an idiopathic cause is reported in up to $50 \%$ of cases compared with less than $20 \%$ in developed nations (Pietrow et al. 2002b; Hari et al. 1995). The rate of anatomical abnormalities was low in this study and in other developing countries compared with $20 \%$ to $30 \%$ in developed countries (Fraser et al. 1999b).This result is perhaps a reflection of better diagnostic and imaging facilities in developed nations, where prenatal examination is routine. Similarly metabolic causes show wide variation from up to $50 \%$ in the United States of America, $16 \%$ in the United Kingdom, 2\% in Armenia and 15\% in North India.

\section{CONCLUSIONS}

Urolithiasis is a serious problem among Sudanese children with early onset of presentation. Proper management of UTI with a careful metabolic assessment of young stone formers is valuable in combating urolithiasis.

\section{REFERENCE}

Aggour, A.; Ziada, A. M.; AbdelHamid, A. Z.; AbdelRahman, S. and Morsi, A. (2009). "Metabolic stone composition in Egyptian children." J. Pediatr. Urol., 5(2):132-135.

Al-Eisa, A. A.; Al-Hunayyan, A. and Gupta, R. (2002). "Pediatric urolithiasis in Kuwait." Int. Urol. Nephrol., 33(1): 3-6.

Al-Rasheed, S.; Al Jurayyan, N. A.; Al Nasser, M. N.; Al-Mugeiren, M. M.; AlSalloum, A. A. and Petterson, B. A. (1995). "Nephrolithiasis in children and adolescents in the South Western region of saudi arabia." Saudi. J. Kidney Dis. Transpl., 6(4): 396-399.

Alaya, A.; Nouri, A. and Najjar, M. F. (2009). "Urolithiasis in Tunisian children: a study of 100 cases." Saudi. J. Kidney Dis. Transpl., 20(6): 1096-1100.

Alaya, A.; Nouri, A. and Najjar, M. F. (2009). "[Prevalence and composition of urolithiasis in a pediatric Tunisian 
population]." Prog. Urol., 19(6): 395400.

Androulakakis, P. A.; Michael, V.; Polychronopoulou, S. and Aghioutantis, C. (1991). "Paediatric urolithiasis in Greece." Br. J. Urol., 67(2): 206-209.

Angwafo, F. F. III; Daudon, M.; Wonkam, A.; Kuwong, P. M. and Kropp, K. A. (2000). "Pediatric urolithiasis in subsaharan Africa: a comparative study in two regions of Cameroon." Eur. Urol., 37(1): 106-111.

Coward, R. J.; Peters, C. J.; Duffy, P. G.; Corry, D.; Kellett, M. J.; Choong, S. and van't Hoff, W. G. (2003). "Epidemiology of paediatric renal stone disease in the UK." Arch. Dis. Child, 88(11): 962-965.

Daudon, M. (2000). "[Component analysis of urinary calculi in the etiologic diagnosis of urolithiasis in the child]." Arch. Pediatr., 7(8): 855-865.

Fraser, M.; Joyce, A. D.; Thomas, D. F.; Eardley, I. and Clark, P. B. (1999b). "Minimally invasive treatment of urinary tract calculi in children." BJU. Int., 84(3): 339-342.

Fraser, M.; Joyce, A. D.; Thomas, D. F.; Eardley, I. and Clark, P. B. (1999a). "Minimally invasive treatment of urinary tract calculi in children." BJU. Int., 84(3): 339-342.

Gearhart, J. P.; Herzberg, G. Z. and Jeffs, R. D. (1991). "Childhood urolithiasis: experiences and advances." Pediatrics, 87(4): 445-450.

Hari, P.; Bagga, A.; Vasudev, V.; Singh, M. and Srivastava, R. N. (1995). "Aetiology of nephrolithiasis in north Indian children." Pediatr. Nephrol., 9(4): 474-475.

Jungers, P.; Joly, D.; Gagnadoux, M. F. and Daudon, M. (2001). "[Cystine lithiasis: physiopathology and medical treatment]." Prog. Urol., 11(1): 122-126.

Kamoun, A.; Daudon, M.; Abdelmoula, J.; Hamzaoui, M.; Chaouachi, B.; Houissa, T.; Zghal, A.; Ben, A. S.; Belkahia, C. and Lakhoua, R. (1999).
"Urolithiasis in Tunisian children: a study of 120 cases based on stone composition." Pediatr. Nephrol., 13 (9): 920-925.

Kamoun, A.; Daudon, M.; Kabaar, N.; Dhaoui, R.; Ben, A. S.; Zghal, A.; Zerilli, L.; Chaouachi, B.; Belkahia, C. and Lakhoua, R. (1995). "[Etiologic factors of urinary lithiasis in Tunisian children]." Prog. Urol., 5(6): 942945.

Kamoun, A.; Zghal, A.; Daudon, M.; Ben, A. S.; Zerelli, L.; Abdelmoula, J.; Chaouachi, B.; Houissa, T.; Belkahia, C. and Lakhoua, R. (1997). "[Urinary calculi in children: contribution of anamnesis, biological exploration and physical analysis of calculi to the etiological diagnosis]." Arch. Pediatr., 4 (7): 629-638.

Milliner, D. S., and Murphy, M. E. (1993). "Urolithiasis in pediatric patients." Mayo Clin. Proc., 68(3): 241-248.

Oner, A.; Demircin, G.; Ipekcioglu, H.; Bulbul, M. and Ecin, N. (1997). "Etiological and clinical patterns of urolithiasis in Turkish children." Eur. Urol., 31(4): 453-458.

Oussama, A.; Kzaiber, F.; Mernari, B.; Semmoud, A. and Daudon, $M$. (2000). "[Analysis of calculi by infrared spectroscopy in children from the Moroccan mid-Atlas region]." Ann. Urol. (Paris), 34(6): 384-390.

Pietrow, P. K.; Pope, J. C.; Adams, M. C.; Shyr, Y. and Brock, J. W. III (2002a). "Clinical outcome of pediatric stone disease." J. Urol., 167(2 Pt 1): 670673.

Pietrow, P. K.; Pope, J. C.; Adams, M. C.; Shyr, Y., and Brock, J. W., III (2002b). "Clinical outcome of pediatric stone disease." J. Urol., 167(2 Pt 1), 670-673.

Stapleton, F. B. (2002). "Childhood stones." Endocrinol. Metab Clin. North Am., 31(4): 1001-15, ix.

Sternberg, K.; Greenfield, S. P.; Williot, P.; and Wan, J. (2005). "Pediatric stone disease: an evolving experience." $J$. Urol., 174 (4 Pt 2): 1711-1714. 


\title{
ARABIC SUMMARY
}

\author{
المكونات الأيضية لحصاوى المجارى البولية عند الأطفال السودانيين

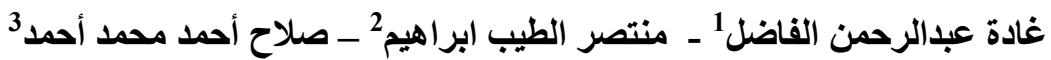

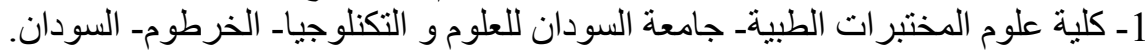

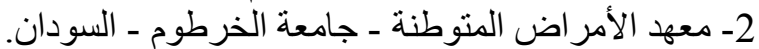 \\ 3 - كلية الطب - جامعة الخرطوم ـ السودان.
}

الالهدف من: هذه الدراسة معرفة مكونات الحصاوي البولية عند الاطفال السودانيين وتقييم بعض العوامل الايضية

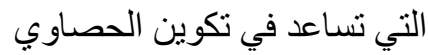

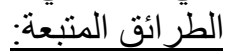

تم تحليل الحصاوي المتكونة عند 175 طفل (129 اولاد، 46 بنات) تتر اوح اعمار هم بين 3 شهور و 16 سنة. نم

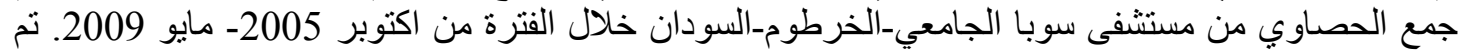

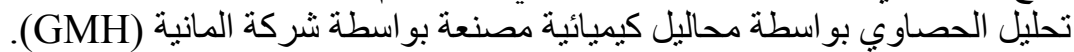

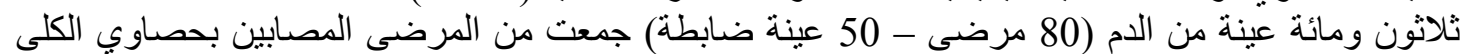

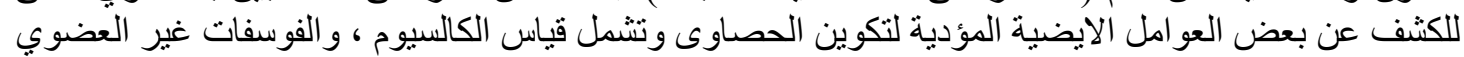

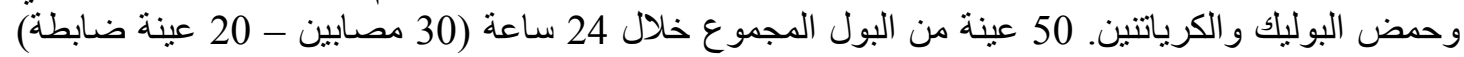
لقياس الكالسيوم و الفوسفات وحمض البوليك التي تم اخر اجها خلال اليوم وقد تم قياسها بجهاز ( COBAS .(INTEGRA 400 PLUS

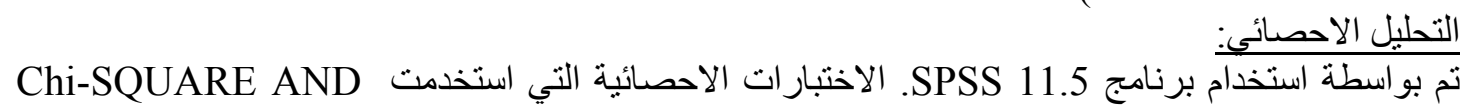
.FISHIR EXACT TEST

النتّائج :

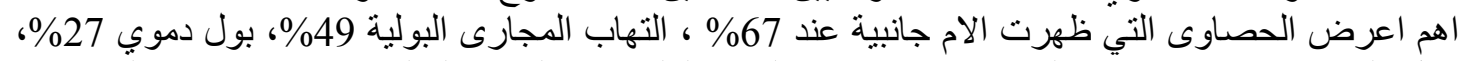

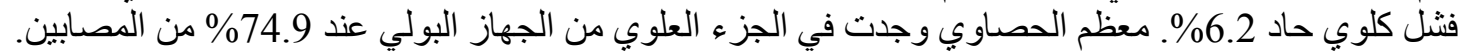

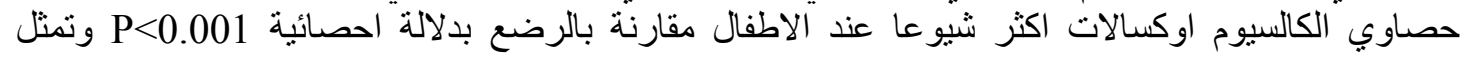

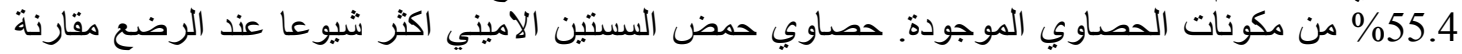

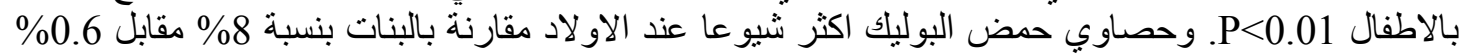

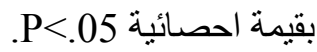

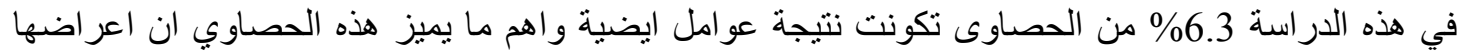

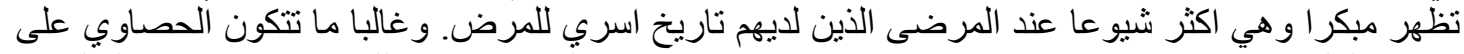

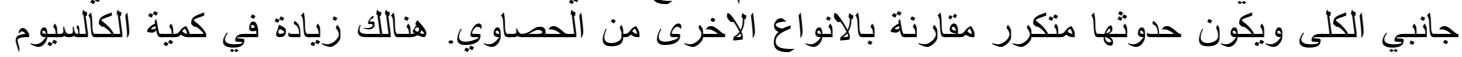

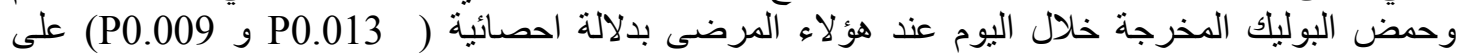
التو الي. 